\title{
Identification of Bioactive Compounds and Possible Mechanism of Hepatoprotective Activity of Ficus microcarpa I. Fil. Bark Extracts in Ethanol-Induced Chronic Hepatic Injury in Rats
}

\author{
Sanjay Javerilal Surana*, Anilkumar Uttamchand Tatiya and Mohan Ganpatrao Kalaskar \\ R. C. Patel Institute of Pharmaceutical Education and Research Shirpur, Dhule - 425 405, Maharashtra, INDIA.
}

\begin{abstract}
Objective: To evaluate the effect of the successive extracts of the FMB on ethanol induced chronic hepatotoxicity. Furthermore, to understand the mechanisms of its pharmacological actions, the in vivo antioxidant activity and major phytoconstituents of FMB were investigated. Methodology: Ficus microcarpa L. fil., (FM) is commonly known as 'Indian Laurel', is used for liver complaints in Indian traditional practice. The hepatoprotective effect of four successive extracts (petroleum ether 60-80o, ethyl acetate, ethanol and aqueous) of FM bark (FMB) were studied in chronic ethanol induced liver damage. The protective potential measured by monitoring biochemical parameters and histopathological alterations. Result: The ethyl acetate extract of FMBE produce significant hepatoprotection by stabilizing the biochemical parameters in a dose dependent manner, comparable to that of standard drug, silymarin; also showed the positive involvement of endogenous antioxidant system. Further, it was confirmed by histology examination of liver. Phytochemical studies confirmed the presence of the phenolic and triterpenoids compounds such as catechin, oleanolic and betulinic acid. Conclusion: Hepatoprotective ability of FMB involves antioxidant mechanism associated with up-regulation of endogenous antioxidant system due to presence of phenolics and triterpenoids. Thus, the present study provides a scientific rationale for the traditional use in the management of chronic liver disorders.

Key words: Hepatoprotective, Ficus microcarpa, Ethanol, Antioxidant, Catechin, Oleanolic acid, Betulinic acid.
\end{abstract}

\section{INTRODUCTION}

Ficus microcarpa L. fil. (Syn: Ficus retusa) (Moraceae), known commonly as Indian Laurel, distributed throughout the hotter parts of India. Its dried leaves, aerial roots, and bark are used for diverse health ailments in traditional and folklore remedies. The ash from F. microcarpa provides the best quality lye for preparing Okinawa Soba, the famous traditional food of Okinawa. ${ }^{1}$ Triterpenoids, fatty alcohol, steroids, coumarin, flavane, 4-hydroxybenzoates and a carotenoid-like compound have been isolated from F. microcarpa bark (FMB) by Kuo and Li. ${ }^{2}$ Phenolic compounds such as protocatechuic acid, catechol, $p$-vinylguaiacol, syringol, $p$-propyl- phenol, vanillin, and syringaldehyde have been identified in F. microcarpa bark through chromatographic and spectroscopic studies. These have been reported to have antioxidant, antibacterial properties in in-vitro studies. ${ }^{3}$ The latex of the plant has reported to contain chintinase, giving rise to antifungal properties. $^{4}$ A remarkable antitussive and expectorant potential has been reported for F. microcarpa. ${ }^{5}$ Traditionally, the bark has a reputation of efficacy in the treatment of liver diseases. ${ }^{6}$ However, there is no scientific literature regarding its usefulness as a hepatoprotective against ethanol induced chronic hepatotoxicity in rats. In continua-
Submission Date: 19-11-2016; Revision Date: 14-03-2017; Accepted Date: 13-07-2017

DOI: $10.5530 / \mathrm{ijper.51.4.104}$ Correspondence: Sanjay Javerilal Surana, R. C. Patel Institute of Pharmaceutical Education and Research Shirpur, Dhule, 425 405, Maharashtra, INDIA.

Phone and Fax: +912563255189 E-mail: kalaskar.mohan@ gmail.com

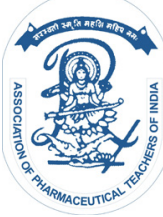

www.ijper.org 
tion to our previous work on hepatoprotective ability in acute models, ${ }^{7}$ the present study was undertaken to evaluate the effect of the successive extracts of the FMB on ethanol induced chronic hepatotoxicity. Furthermore, to understand the mechanisms of its pharmacological actions, the in vivo antioxidant activity and major phytoconstituents of FMB were investigated.

\section{MATERIALS AND METHODS}

\section{Materials}

Silymarin from Micro Labs Ltd. (Bengaluru, india), catechin (Sigma-Aldrich Chemie, Steinheim, Germany); (Loba Chemie, Mumbai); Diagnostic kits were purchased from Ranbaxy diagnostic Ltd (Baddi, India); Tris- $\mathrm{HCl}$ was from Loba Chemie Pvt Ltd. (Mumbai, India). All other reagents and solvents used of analytical grade.

\section{Plant collection and extraction}

FMB was collected from Lonawala, Maharashtra, during August 2009 and authenticated by the botany department of SSVPS College, Dhule, Maharashtra. The bark was washed, cleaned, shade dried, powdered, and passed through a 40-mesh sieve. It was stored in a tightly closed container. A voucher specimen (RCP-42) was authenticated and deposited in Pharmacognosy department.

The FMB were extracted successively with petroleum ether $\left(60-80^{\circ}\right)(\mathrm{PE})$, ethyl acetate (EA) and ethanol (EO) by hot continuous percolation. The resultant marc was macerated with water (AQ) twice at $25^{\circ} \mathrm{C}$ for $48 \mathrm{~h}$. Extracts after filtration were dried using a rotary evaporator (BUCHI, Rotavapor R - 215) under reduced pressure. The dry extract obtained with each solvent was weighed and percentage yield of extracts were $2.71 \pm 0.29,1.37$ $\pm 0.26,7.08 \pm 0.27$ and $3.35 \pm 0.26 \% \mathrm{w} / \mathrm{w}$ respectively.

\section{Phytochemical studies:}

Preliminary qualitative phytochemical screening of FMB extracts (FMBE) showed the presence of lipids, triterpenoids, steroids, saponins, flavonoids, phenolic acid, quinones, tannins, carbohydrates, protein and amino acids, which was confirmed by qualitative tests.

The present of polyphenols and triterpenoids in FMBE were estimated qualitatively by HPLC, as per the method described by Pawar and Surana. ${ }^{8}$ The HPLC analysis confirmed the presence of catechin, oleanolic and betulinic acid in successive EA extract of FMB using standard marker. A Shimadzu HPLC system with LC-10AT, UV detector (Spectra System UV1000), and Luna $\mathrm{C}_{18}$ reverse-phase column $(250 \mathrm{~mm} \times 4.6 \mathrm{~mm}$, i.d. particle size $5 \mu$ ) was used. The isocratic mode with acetonitrile: water $(80: 20, \mathrm{v} / \mathrm{v})$ at
$280 \mathrm{~nm}, 0.8 \mathrm{ml} / \mathrm{min}$ flow rate for catechin; while, the mobile phase of acetonitrile: water $(85: 15, \mathrm{v} / \mathrm{v})$ at $215 \mathrm{~nm}$ with flow rate $0.3 \mathrm{ml} / \mathrm{min}$ for, oleanolic and betulinic acid were used. The flow rate and column temperature were $25^{\circ} \mathrm{C}$, with $\mathrm{UV}$ absorbance detection.

\section{Animals}

The experimental protocol (RCPIPER/2008-9/12) described in the present study was approved by the Institutional Animal Ethics Committee (IAEC) of R. C. Patel institute of pharmaceutical education research, Shirpur, India, with the permission from Committee for the Purpose of Control and Supervision of Experiments on Animals (CPCSEA), Ministry of Social Justice and Empowerment, Government of India. Healthy adult Wistar rats (200-250 g). They were housed under standard laboratory conditions and were fed commercial rat feed (Lipton India Ltd., Mumbai, India) and boiled water, ad libitum.

\section{Ethanol induced hepatotoxicity}

Hepatoprotective study was carried out as described by Gujrati and co. ${ }^{9}$ animals were randomly divided into 11 groups of 6 animals each. The animals were pretreated once daily with vehicle $(2 \% \mathrm{v} / \mathrm{v}$, tween 80$) / \mathrm{PE}, \mathrm{EA}, \mathrm{EO}, \mathrm{AQ}$ extracts of FMB (100 and $200 \mathrm{mg} / \mathrm{kg}) /$ silymarin $(100 \mathrm{mg} / \mathrm{kg}$, standard drug) orally, $1 \mathrm{~h}$ before ethanol administration. All the animals, except normal control group, received 20\% ethanol (3.76 g/ $/ \mathrm{kg}$, p.o.) twice daily for period of 28 days. On $29^{\text {th }}$ day, the blood collected by retro-orbital puncture under ether anesthesia, serum was separated by centrifugation at $2500 \mathrm{rpm}$ at $4^{\circ} \mathrm{C}$ for $15 \mathrm{~min}$ and used for estimation of various biochemical parameters such as serum glutamic oxaloacetic transaminase (SGOT), serum glutamic pyruvic transaminase (SGPT), serum alkaline phosphatase (ALP), total bilirubin (TB), direct bilirubin (DB) and total protein (TP). Then the animals were sacrificed under ether anesthesia. The livers from all the animals were collected, washed, and used for antioxidant and histological studies.

\section{In-vivo antioxidant activity}

For estimating antioxidant activity, the excised livers were rinsed in ice-cold normal saline, followed by $0.15 \mathrm{M}$ Tris- $\mathrm{HCl}(\mathrm{pH}$ 7.4) blotted dried and weighed. A $10 \% \mathrm{w} / \mathrm{v}$ of homogenate was prepared in 0.15 $\mathrm{M}$ Tris- $\mathrm{HCl}$ buffer and processed for the estimation of lipid peroxidation. ${ }^{10}$ The remaining homogenate was centrifuged at $15000 \mathrm{rpm}$ for $15 \mathrm{~min}$ at $4^{\circ} \mathrm{C}$. The supernatant thus obtained was used for the 
estimation of super oxide dismutase (SOD) and catalase (CAT) ${ }^{11,12}$

\section{Histopathological studies}

The liver samples were fixed in 10\% buffered formalin for $48 \mathrm{~h}$. The formalin-fixed liver samples were stained with haematoxylin-eosin ( $\mathrm{H}$ and $\mathrm{E}$ ) for photomicroscopic observation of the histological architecture, using a Motic digital microscope.

\section{Statistical analysis}

Results are expressed as mean \pm S.E.M. The statistical difference was analyzed by one-way analysis of variance followed by Dunnett test, significance was calculated as the $p$ value, and $p$ values of less than 0.05 were regarded as statistically significant.

\section{RESULTS}

The HPLC analysis of FMB, EA extract showed presence of polyphenol, catechin, oleanolic and betulinic acid (Figure 1).

Administration of ethanol at dose of $3.76 \mathrm{~g} / \mathrm{kg}$ p.o. twice daily for period of 28 days to Wister rats, results significant elevations in biochemical parameters such as SGOT, SGPT, ALP, TP, TB and DB in ethanol control as compared to normal control indicates liver toxicity. In the ethanol control group, serum SGOT, SGPT, ALP, $\mathrm{TB}$ and $\mathrm{DB}$ were increased to $285.6 \mathrm{IU} / 1,149.5 \mathrm{IU} / 1$, $231 \mathrm{IU} / 1,1.6 \mathrm{mg} / \mathrm{dl}$ and $1.48 \mathrm{mg} / \mathrm{dl}$, respectively, while TP was decreased to $3.26 \mathrm{gm} \%$. Whereas, these values were found $79.96 \mathrm{IU} / 1,41.57 \mathrm{IU} / 1,91.84 \mathrm{IU} / 1,0.21$ $\mathrm{mg} / \mathrm{dl}, 0.14 \mathrm{mg} / \mathrm{dl}$ and $6.14 \mathrm{gm} \%$, in normal control group, respectively. The elevated levels of serum AST, ALT, ALP, TP, TB, and DB were significantly reduced and demonstrated dose dependent manner in the animals

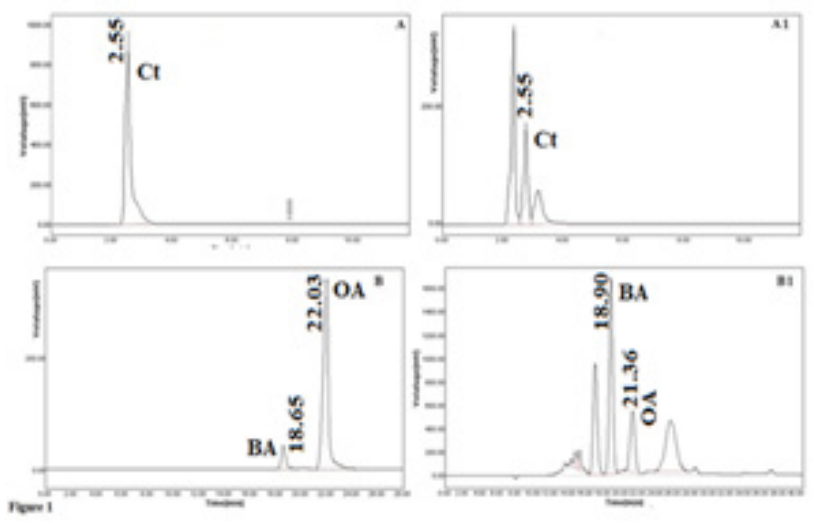

Figure 1: HPLC chromatogram of (A) authentic standards catechin, (B) oleanolic acid and betulinic acid were identified (A-1, B-1) in FMB ethyl acetate extract.

Ct: Catechin; OA: oleanolic acid and BA: betulinic acid.
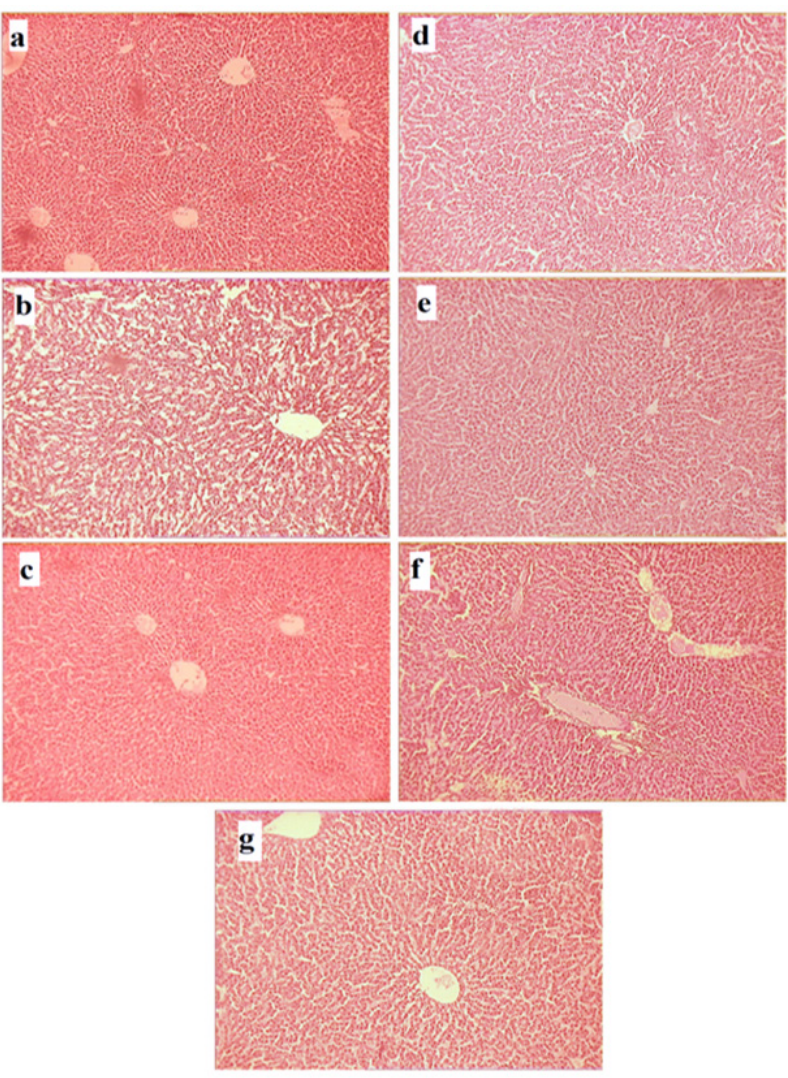

Figure 2: Histopathological architecture in the liver of control and experimental rats treated with ethanol (H\&E X100).

a - Normal Control, b - Ethanol Control, c - Silymarin treated, d - Petroleum ether extract treated, e - Ethyl acetate extract treated, $\mathbf{f}$ - Ethanol extract treated, $\mathbf{g}$ - Aqueous extract treated.

groups treated with FMBE. Treatment with EA extract showed highest hepatoprotective activity (Table 1) almost effective as silymarin, reference drug. The PE extract showed significant activity, when compared the other extracts but not as effective as the silymarin and EA extract.

The effect of FMBE on lipid peroxidation (Thiobarbituric acid reactive substance, TBRAS), tissue antioxidant defense enzymes such as SOD, CAT are shown in Table 2. The levels of hepatic TBRAS significantly increased in ethanol control group (8.25 nmol/mg), this elevated tissue TBRAS concentration was lowered significantly by pretreatment with the higher dose of ethyl acetate FMB extract $(2.67 \mathrm{nmol} / \mathrm{mg})$, when compared with other extracts. Hepatic SOD and CAT levels were decreased in ethanol control group (40.47 $\mathrm{U} / \mathrm{mg}, 4.39 \mathrm{U} / \mathrm{mg}$ ). Pretreatment with the higher dose of EA FMBE $(200 \mathrm{mg} / \mathrm{kg})$ exhibited protection against ethanol-induced hepatic SOD and CAT depletion, as evidenced by reversing to approximate the normal level 
Table 1: Effects FMBE on rat serum biochemical parameters after 28 days ethanol administration.

\begin{tabular}{|c|c|c|c|c|c|c|}
\hline Group & SGOT (IU/I) & SGPT (IU/I) & ALP (IU/I) & TB (mg/dl) & DB (mg/dl) & TP $(g m \%)$ \\
\hline Normal Control & $79.96 \pm 6.68$ & $41.57 \pm 3.97$ & $91.84 \pm 3.58$ & $0.21 \pm 0.04$ & $0.14 \pm 0.02$ & $6.14 \pm 0.08$ \\
\hline Ethanol control & $285.6 \pm 13.91^{a}$ & $149.50 \pm 6^{a}$ & $231 \pm 12.27^{a}$ & $1.6 \pm 0.21^{a}$ & $1.48 \pm 0.11^{a}$ & $3.26 \pm 0.17^{\mathrm{a}}$ \\
\hline Silymarin & $89 \pm 7.35^{b}$ & $47.14 \pm 5.73^{b}$ & $97.64 \pm 6.54^{b}$ & $0.32 \pm 0.03^{b}$ & $0.18 \pm 0.01^{b}$ & $5.72 \pm 0.16^{b}$ \\
\hline Eth + PFM (100mg) & $171.50 \pm 10.02^{b}$ & $106.30 \pm 5.77^{b}$ & $194.30 \pm 5.65^{d}$ & $1.16 \pm 0.16^{c}$ & $1.07 \pm 0.12^{b}$ & $3.84 \pm 0.16^{\circ}$ \\
\hline Eth + PFM (200mg) & $101.20 \pm 9.51^{b}$ & $61.80 \pm 4.96^{b}$ & $128.20 \pm 9.35^{b}$ & $0.57 \pm 0.08^{b}$ & $0.48 \pm 0.03^{b}$ & $4.83 \pm 0.25^{b}$ \\
\hline Eth + EAFM (100mg) & $151.10 \pm 9.75^{b}$ & $105.00 \pm 7.37^{b}$ & $169.50 \pm 10.06^{b}$ & $0.98 \pm 0.07^{b}$ & $0.74 \pm 0.12^{b}$ & $3.85 \pm 0.25^{d}$ \\
\hline Eth +EAFM (200mg) & $85.25 \pm 2.81^{b}$ & $59.07 \pm 3.53^{b}$ & $108.70 \pm 8.35^{b}$ & $0.46 \pm 0.06^{b}$ & $0.27 \pm 0.04^{b}$ & $5.16 \pm 0.28^{b}$ \\
\hline Eth + EOFM (100mg) & $236.70 \pm 12.99^{b}$ & $118.20 \pm 9.88^{c}$ & $200.00 \pm 9.36^{d}$ & $3.21 \pm 0.1^{b}$ & $1.02 \pm 0.09^{b}$ & $3.57 \pm 0.17^{\circ}$ \\
\hline Alc + EOFM (200mg) & $139.70 \pm 9.83^{b}$ & $92.08 \pm 6.89^{b}$ & $147.70 \pm 8.37^{b}$ & $0.77 \pm 0.07^{b}$ & $0.71 \pm 0.06^{b}$ & $4.27 \pm 0.19^{b}$ \\
\hline Eth + AQFM (100mg) & $272.40 \pm 11.53^{d}$ & $134.00 \pm 7.47^{d}$ & $210.70 \pm 10.66^{d}$ & $1.46 \pm 0.12^{d}$ & $1.34 \pm 0.1^{d}$ & $3.35 \pm 0.13^{\circ}$ \\
\hline Eth +AQFM (200mg) & $216.40 \pm 12.95^{b}$ & $101.00 \pm 5.81^{b}$ & $167.10 \pm 10.29^{b}$ & $1.17 \pm 0.11^{c}$ & $0.96 \pm 0.07^{b}$ & $4.08 \pm 0.19^{\circ}$ \\
\hline
\end{tabular}

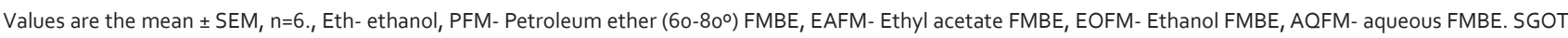
= serum glutamate oxaloacetate transaminase, $\mathrm{SGPT}=$ serum glutamate pyruvate transaminase, $\mathrm{ALP}=$ alkaline phosphatase, $\mathrm{DB}=$ direct bilirubin, $\mathrm{TB}=$ total bilirubin, $\mathrm{TP}$ $=$ total protein.

a $\mathrm{P}<0.01$ when compared with control.

b $P<0.01$ when compared with toxicant.

c $P<0.05$ when compared with toxicant.

d $P>0.05$ when compared with toxicant.

\begin{tabular}{|c|c|c|c|}
\hline \multicolumn{4}{|c|}{$\begin{array}{c}\text { Table 2: Effects of FMBE extracts on rat liver TBRAS, CAT, and SOD levels } \\
\text { after } 28 \text { days ethanol administration. }\end{array}$} \\
\hline Group & $\begin{array}{c}\text { TBRAS } \\
\text { (nmol/mg protein) }\end{array}$ & $\begin{array}{c}\text { Catalase } \\
\text { (U/min/mg protein) }\end{array}$ & $\begin{array}{c}\text { SOD } \\
\text { (U/mg protein) }\end{array}$ \\
\hline Normal Control & $4.70 \pm 0.13^{\mathrm{m}}$ & $78.76 \pm 4.47$ & $5.74 \pm 0.03$ \\
\hline Ethanol control & $9.53 \pm 0.35^{\mathrm{a}}$ & $40.47 \pm 2.55^{\mathrm{a}}$ & $2.52 \pm 0.04^{\mathrm{a}}$ \\
\hline Silymarin & $4.98 \pm 0.08^{\mathrm{b}}$ & $70.03 \pm 1.88^{\mathrm{b}}$ & $5.57 \pm 0.04^{\mathrm{b}}$ \\
\hline Eth + PFM (100mg) & $6.85 \pm 0.16^{\mathrm{b}}$ & $55.71 \pm 2.15^{\mathrm{b}}$ & $3.91 \pm 0.02^{\mathrm{b}}$ \\
\hline Eth + PFM (200mg) & $6.22 \pm 0.14^{\mathrm{b}}$ & $63.65 \pm 3.23^{\mathrm{b}}$ & $4.34 \pm 0.05^{\mathrm{b}}$ \\
\hline Eth + EAFM (100mg) & $6.53 \pm 0.1^{\mathrm{b}}$ & $57.52 \pm 2.67^{\mathrm{b}}$ & $4.28 \pm 0.06^{\mathrm{b}}$ \\
\hline Eth +EAFM (200mg) & $5.28 \pm 0.13^{\mathrm{b}}$ & $66.96 \pm 2.23^{\mathrm{b}}$ & $5.22 \pm 0.06^{\mathrm{b}}$ \\
\hline Eth + EOFM (100mg) & $7.14 \pm 0.08^{\mathrm{b}}$ & $49.24 \pm 1.88^{\mathrm{d}}$ & $3.79 \pm 0.07^{\mathrm{b}}$ \\
\hline Eth + EOFM (200mg) & $6.66 \pm 0.06^{\mathrm{b}}$ & $58.63 \pm 2.21^{\mathrm{b}}$ & $4.21 \pm 0.05^{\mathrm{b}}$ \\
\hline Eth + AQFM (100mg) $^{\mathrm{b}}$ & $6.91 \pm 0.12^{\mathrm{b}}$ & $47.41 \pm 2.90^{\mathrm{d}}$ & $3.52 \pm 0.04^{\mathrm{b}}$ \\
\hline Eth +AQFM (200mg) & $6.34 \pm 0.08^{\mathrm{b}}$ & $54.72 \pm 2.54^{\mathrm{c}}$ & $4.00 \pm 0.05^{\mathrm{b}}$ \\
\hline
\end{tabular}

Values are the mean $\pm \mathrm{SEM}, \mathrm{n}=6$., Eth- ethanol, PFM- Petroleum ether $\left(60-80^{\circ}\right) \mathrm{FMBE}, \mathrm{EAFM}$ - Ethyl acetate FMBE, EOFM- Ethanol FMBE, AQFM- aqueous FMBE. SGOT = serum glutamate oxaloacetate transaminase, $\mathrm{SGPT}=$ serum glutamate pyruvate transaminase, $\mathrm{ALP}=$ alkaline phosphatase, $\mathrm{DB}=$ direct bilirubin, $\mathrm{TB}=$ total bilirubin, $\mathrm{TP}=$ total protein.

a $\mathrm{P}<0.01$ when compared with control.

b $P<0.01$ when compared with toxicant.

c $P<0.05$ when compared with toxicant.

$\mathrm{d} P>0.05$ when compared with toxicant.

(66.96 and $8.54 \mathrm{U} / \mathrm{mg}$ ) and was close to that of silymarin (40.47 and $8.83 \mathrm{U} / \mathrm{mg}$ ), when compared with other extracts. The PE extract of FMB (200 mg/kg) also showed significant protective effect against ethanolinduced elevated levels of TBRAS, SOD, and CAT (Table 2).
The histology of the normal control showed a normal architecture of the liver (Figure 2a). In ethanol control, there was a microvascular fatty change (Figure 2b). Treatment with FMBE showed minimal fatty changes. However, ethyl acetate extract (Figure 2e) and silymarin (Figure 2c) treated group showed less microvascular fatty changes and their architectures were normal, indi- 
cating the hepatoprotective effect of this extract than other extracts of FMB (Figure 2d-g).

\section{DISCUSSION}

The bark of Ficus microcarpa is well known Indian traditional plant, strongly recommended in liver diseases. To this connection, FMB were evaluated for its hepatoprotective potential in chronic hepatotoxicity in animal models and their mechanism in experiential animals.

The liver is the key organ involved in regulation of almost all the biochemical pathways. ${ }^{13}$ Ethanol is metabolized in liver through oxidation, causes accumulation of reactive oxygen species (ROS); like superoxide, hydroxyl radical, and hydrogen peroxide, ${ }^{14}$ ultimately leading to injury of hepatocytes. ${ }^{15-17}$ These are considered associated with ethanolic liver disease (ALD).

Chronic ethanol intake leads to many cellular and tissue abnormalities; thereby leakage of cellular enzymes and other related biochemical parameters. ${ }^{18}$ In the present investigation, ethanol results in alteration of conventional hepatic marker and enzymes i.e. SGOT, SGPT, ALP, TB, and DB in the serum. Further, it reduces the protein synthesis is further indication of hepatocellular damage. These findings indicate changes in the permeability of the plasma membrane. This might be due to peroxidation of lipid by the generation of oxygen as a free radical. The treatment with the FMBE extracts significantly stabilizes these biochemical parameters. Among the extracts, the EA extract treated group offered significant protection against chronic ethanolintoxicated rats. This effect is in agreement with the commonly accepted view that serum levels of transaminases and other biochemical markers return to normal with the healing of hepatic parenchyma and regeneration of hepatocytes. ${ }^{19}$ These biochemical findings further substantiated by histopathological studies.

Many pathways have been suggested to play a role on how ethanol induces a state of "oxidative stress". ${ }^{20}$ In present study, the involvement of oxidative stress in chronic ethanol-induced liver injury and showed significant protective effect of FMB EA extract, as evidenced by decreasing the level of TBRAS and inhibiting the decrease of SOD and CAT activity, suggesting the stability of the biliary function during injury. The attenuation of ethanol-induced oxidative stress by FMBE was found in dose dependant manner. The EA extract of FMB offered protection comparable to standard drug, silymarin. This was probably due to its ability to restore the balance between generation and clearance of ROS. In present study, attempt was carried out to find the major phytoconstituents responsible for hepatoprotec- tive activity. The results indicated that different FMBE offers different degree of protection. The EA extract showed higher in vivo antioxidant and hepatoprotective activity compared with tested extracts. The HPLC analysis of FMB EA extracts showed the presence polyphenols, catechin and triterpenoids, oleanolic and betulinic acid as the major components.

Thus, it may be hypothesized that, polyphenolic and triterpenoids such as catechin, oleanolic and betulinic acid other related compounds in ethyl acetate extract of FMB could be considered responsible for hepatoprotective activity due to its antioxidant effect. In earlier studies, catechin, betulinic acid and oleanolic acid proved as strong antioxidant in in-vitro and in-vivo studies. Betulinic acid significantly decreased ethanol-induced superoxide anion production and acting as antioxidants, inhibitors of cytokine production, and inhibitors of TGF- $\beta$, and $\mathrm{NF} \varkappa \mathrm{B} / \mathrm{I} \varkappa \mathrm{B}$ transduction signaling; ${ }^{21}$ While oleanolic acid decreased mainly ethanol-induced hydrogen peroxide production and has glutathione regeneration capacity. ${ }^{22}$ In addition catechin has cytoprotective effect through nuclear factor-E2-related factor $2(\mathrm{Nrf} 2)$ which extensively proven to be a strong activator of antioxidant-responsive element (ARE)-mediated gene expression pathway. ${ }^{7-25}$

\section{CONCLUSION}

It can conclude that ethyl acetate extract with maximum antioxidant activity was the most potent heptoprotective extract among tested extracts. it can assume that the hepatoprotective effect of F. microcarpa may be mix mechanism as rejunivation of endogenious antioxidant meachanism by ARE activation through nuclear factorE2-related factor 2 (Nrf2) and supported with inhibition of TGF- $\beta$, and $\mathrm{NF} \varkappa \mathrm{B} / \mathrm{I} \varkappa \mathrm{B}$ transduction signaling. Our findings support the reported therapeutic use of this plant as a hepatoprotective agent in Indian system of medicine. Present study highlighting the possible mechanism of action of its anti-hepatitis activity.

\section{ACKNOWLEDGEMENT}

The authors would like to thank Prof. Dr. D. A. Patil from the Prof, Dept of Botany, SSVPS College, Dhule, MS. for the identification of the plant.

\section{CONFLICT OF INTEREST}

None of the authors has a conflict of interest to disclose. 


\section{ABBREVIATION USED}

ALD: Ethanolic Liver Disease; ALP: Serum alkaline phosphatase; TB: Total bilirubin; ARE: Antioxidantresponsive element; CAT: Catalase; DB: Direct Bilirubin; EO: Ethanol; FMB: F. microcarpa bark; FMBE: FMB Extracts; $\mathbf{H}$ and E: Haematoxylin-Eosin; HPLC: High Pressure Liquid Chromatogram; NFB: Nuclear Factor Kappa-Light-Chain-Enhancer of activated B cells; Nrf2: Nuclear Factor-E2-Related Factor 2; PE: Petroleum Ether (60-80 $)$; EA: Ethyl Acetate; SGOT: Serum Glutamic Oxaloacetic Transaminase; SGPT: Serum Glutamic Pyruvic Transaminase; SOD: Super Oxide Dismutase; TBRAS: Thiobarbituric Acid Reactive Substance; TGF: Transforming Growth Factor Beta; TP: Total Protein.

\section{REFERENCE}

1. Nakama Y. Science Bulletin of the College of Agriculture-University of the Ryukyus (Japan). (2003).

2. Kuo YH, Li YC. Constituents of the Bark of Ficus microcarpa Lf. Journal of the Chinese Chemical Society. 1997;44(3):321-5. https://doi.org/10.1002/ jccs.199700048I.

3. Ao C, Li A, Elzaawely AA, Xuan TD, Tawata S. Evaluation of antioxidant and antibacterial activities of Ficus microcarpa L. fil. extract. Food control. 2008;19(10):940-8. https://doi.org/10.1016/j.foodcont.2007.09.007.

4. Taira T, Ohdomari A, Nakama N, Shimoji M, Ishihara M. Characterization and antifungal activity of gazyumaru (Ficus microcarpa) latex chitinases: both the chitin-binding and the antifungal activities of class I chitinase are reinforced with increasing ionic strength. Bioscience, biotechnology, and biochemistry. 2005;69(4):811-8. https://doi.org/10.1271/bbb.69.811.

5. Liu J, Liu Y, Klaassen CD., Zhongguo yao li xue bao= Acta pharmacologica Sinica(1995). 16;97-102

6. Kirtikar K, Basu B, Blatter E, Caius JF, Mhaskar KS, editors. 3,1707-8 (1987).

7. Kalaskar MG, Surana SJ. Indian medicinal plants Indian medicinal plants III, 1994. Journal of natural medicines. 2011;65(3):633-40. https://doi. org/10.1007/s11418-011-0532-; PMid:21625948

8. Pawar CR, Surana SJ. Estimation of gallic acid, epicatechin and quercetin in aesalpiniaceae species by HPLC. Pharmacologyonline. 2009;3:837-46.

9. Gujrati V, Patel N, Rao VN, Nandakumar K, Gouda TS, Shalam MD, Kumar SS. Hepatoprotective activity of alcoholic and aqueous extracts of leaves of Tylophora indica (Linn.) in rats. Indian journal of pharmacology. 2007;39(1):43. https://doi.org/10.4103/0253-7613.30763.

10. Ohkawa H, Ohishi N, Yagi K. Assay for lipid peroxides in animal tissues by thiobarbituric acid reaction. Analytical biochemistry. 1979;95(2):351-8. https://doi.org/10.1016/0003-2697(79)90738-3
11. Aebi H. [13] Catalase in vitro. Methods in enzymology. 1984;105:121-6. https://doi.org/10.1016/S0076-6879(84)05016-3.

12. Kakkar P, Das B, Viswanathan PN.Indian J Biochem Biophys. 21, 130-2 (1984). PMid:6490072.

13. Ward FM, Daly MJ. Hepatic disease. clinical pharmacy and therapeutics (Walker R. and C. Edwards Eds.). Churchill livingstone, New York. 1999:195-212.

14. Nordmann $\mathrm{R}$, Ribière $\mathrm{C}$, Rouach $\mathrm{H}$. Implication of free radical mechanisms in ethanol-induced cellular injury. Free Radical Biology and Medicine. 1992;12(3):219-40. https://doi.org/10.1016/0891-5849(92)90030-K.

15. Kurose IW, Higuchi HA, Kato SH, Miura SO, Watanabe NA, Kamegaya YO, Tomita KE, Takaishi MA, Horie YO, Fukuda MA, Mizukami K. Oxidative stress on mitochondria and cell membrane of cultured rat hepatocytes and perfused liver exposed to ethanol. Gastroenterology. 1997s;112(4):1331-43. https:// doi.org/10.1016/S0016-5085(97)70147-1.

16. Navasumrit P, Ward TH, Dodd NJ, O'Connor PJ. Ethanol-induced free radicals and hepatic DNA strand breaks are prevented in vivo by antioxidants: effects of acute and chronic ethanol exposure. Carcinogenesis. 2000;21(1):93-9. https://doi.org/10.1093/carcin/21.1.93.

17. Rouach H, Fataccioli V, Gentil M, French SW, Morimoto M, et al. Effect of chronic ethanol feeding on lipid peroxidation and protein oxidation in relation to liver pathology. Hepatology. 1997;25(2):351-5. https://doi.org/10.1002/ hep.510250216; PMid:9021946.

18. Drotman RB, Lawhorn GT. Serum enzymes as indicators of chemically induced liver damage. Drug and chemical toxicology. 1978;1(2):163-71. https://doi.org/10.3109/01480547809034433; PMid:755666

19. Thabrew MI, Joice PD, Rajatissa W. A comparative study of the efficacy of Pavetta indica and Osbeckia octandra in the treatment of liver dysfunction. Planta medica. 1987 Jun;53(03):239-41. https://doi. org/10.1055/s-2006-962691; PMid:3628555.

20. de la Rosa LC, Moshage H, Nieto N. Hepatocyte oxidant stress and alcoholic liver disease. Revista Espanola de Enfermedades Digestivas. 2008;100(3):156.

21. Szuster-Ciesielska A, Kandefer-Szersze- M. Protective effects of betulin and betulinic acid against ethanol-induced cytotoxicity in HepG2 cells. Pharmacol Rep. 2005;57(5):588. PMid:16227641.

22. Yim TK, Wu WK, Pak WF, Ko KM. Hepatoprotective action of an oleanolic acid-enriched extract of Ligustrum lucidum fruits is mediated through an enhancement on hepatic glutathione regeneration capacity in mice. Phytotherapy Research. 2001;15(7):589-92. https://doi.org/10.1002/ptr.878; PMid:11746839.

23. Skrzydlewska E, Ostrowska J, Stankiewicz A, Farbiszewski R. Green tea as a potent antioxidant in alcohol intoxication. Addiction biology. 2002;7(3):307-14. https://doi.org/10.1080/13556210220139523; PMid:12126490.

24. Liu LH, Wang LS, Liu XM. Comparison of antitussive, expectorant and antiasthmatic activities of different extracts from Ficus microcarpa. Journal of Medicinal Plants Research. 2009;3(8):596-9.

25. Baltaziak M, Skrzydlewska E, Sulik A, Famulski W, Koda M. Green tea as an antioxidant which protects against alcohol induced injury in rats-a histopathological examination. FOLIA MORPHOLOGICA-WARSZAWAENGLISH EDITION-. 2004;63(1):123-6.

\section{SUMMARY}

- The bark of Ficus microcarpa is well known Indian traditional plant, strongly recommended in liver diseases. The ethyl acetate extract showed higher in vivo antioxidant and hepatoprotective activity compared with other successive extracts.

- Many pathways have been suggested to play a role on how ethanol induces a state of oxidative stress and heptotoxicity. With literature support and on the basis of our finding it can assume that the hepatoprotective effect of $F$. microcarpa may be mix mechanism as rejunivation of endogenous antioxidant mechanism by ARE activation through nuclear factor-E2-related factor 2 (Nrf2) and supported with inhibition of TGF- $\beta$, and NFKB/lkB transduction signaling.

- The HPLC analysis of FMB EA extracts showed the presence polyphenols, catechin and triterpenoids, oleanolic and betulinic acid as the major components and these Phytochemical along with other related constituents could be considered responsible for hepatoprotective activity due to its antioxidant effect.

- Our findings support the reported therapeutic use of this plant as a hepatoprotective agent in Indian system of medicine. Present study highlighting the possible mechanism of action of its anti-hepatitis activity. 


\section{PICTORIAL ABSTRACT}

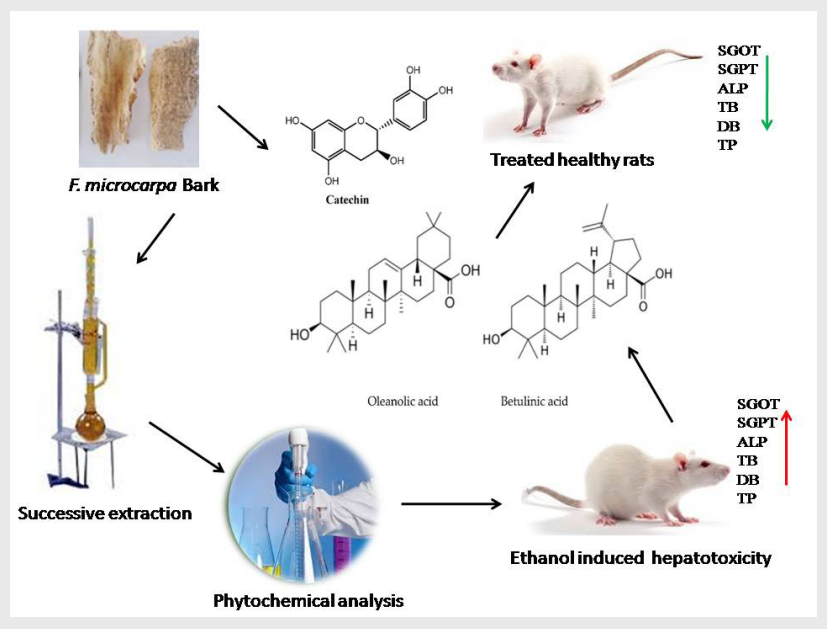

\section{About Authors}

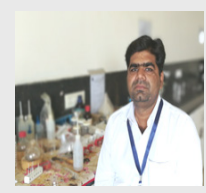

Dr. Mohan G. Kalaskar: Associate Professor, Department of Pharmacognosy, RC Patel Institute of Pharmaceutical Education and Research, Shirpur. He has published more than 30 peer reviewed research articles in international journals. He has six books in his credits in the field of Pharmacognosy and traditional medicine. The research area includes ethnobotany, herbal drug standardization and phytopharmacology of herbal medicine. At present working on various government and nongovernment funded research projects.

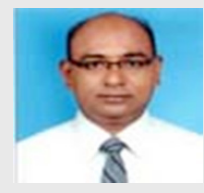

Dr. Anil U. Tatiya: Professor, Department of Pharmacognosy, RC Patel Institute of Pharmaceutical Education and Research, Shirpur. He has published more than 70 peer reviewed research articles in national and international journals. He has two books in his credits in the field of Pharmacognosy and cosmetics. He has holding the position of Asian regional editor for ANSI net and science alert \& several journal of repute. His research area includes herbal formulation development, pharmacokinetic and pharmacodynamic of herbs and their formulation. At present he is working on several government and industrial research projects. More than 30 lakhs research grant received in his credit from AICTE.

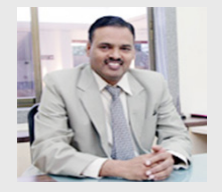

Dr. Sanjay J. Surana: Principal \& Professor, Department of Pharmacognosy, RC Patel Institute of Pharmaceutical Education and Research, Shirpur. He has published more than 250 peer reviewed research articles in national $\&$ international journals. He has published five books in the field of Pharmacognosy and cosmetics. He is recipients of Best Teacher award by Govt.of Maharashtra and Best Principal award from APTI, India. The research area includes development of herbal cosmetics. He has received several grants from statutory body of Indian government.

Cite this article: Surana SJ, Tatiya AU and Kalaskar MG. Identification of Bioactive Compounds and Possible Mechanism of Hepatoprotective Activity of Ficus microcarpa I. Fil. Bark Extracts in Ethanol-Induced Chronic Hepatic Injury in Rats. Indian J of Pharmaceutical Education and Research. 2017;51(4):706-12. 